\title{
Silvio O Conte National Center For Polymer Research, University of Massachusetts Amherst
}

マサチューセッツ大学アマースト校（図 1) は, 農科大 学として 1863 年に設立され，クラーク博士が教鞭をとっ たことでも有名である. 現在は, 約 18,000 人の学部 生, 5,000 人の院生, 約 1,200 名の教職員が在籍し, 約 3,300 のプログラムを有する.

この歴史ある Amherst 校に, 1994 年, 全米でも届指の 高分子に関する研究を行うため，5,600万ドルを投じて Silvio O Conte National Center for Polymer Research (図 2）という高分子に関する研究センターが設立されたそ の名前は，多大な貢献をした Silvio O Conte 連邦議会議貝 にちなんで名づけられた。本施設は，1961年に創立され たPolymer Research Institute を前身とする Polymer Science \& Engineering Department (PSE) の研究施設とし て利用されている.PSEは, 近年, 高分子に関する研究 · 教育において, 全米でトップの大学院としてランクされて いる (U.S. News and World Report).

PSEには 17 名の教官, 常時 80〜 100 名の博士候補学生, さらに多数のポスドク, 客貝教授, 研究員が在籍しており, 国際色豊かである。

主な教官およびその研究内容は下記の通りである，研究 内容は多岐にわたり，高分子研究における広範囲を網羅し

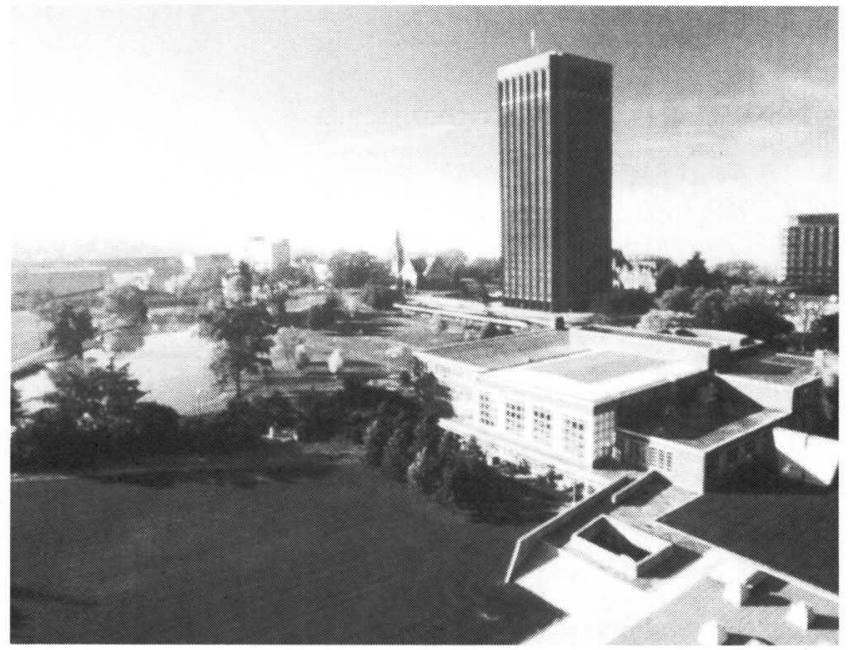

図 1 マサチューセッツ大学アマースト校

\footnotetext{
* Kimura, Masahiro

東レ(侏) 滋賀事業場フィルム研究所

大津市園山 1-1-1（テ520-8558）

2002.9.15 受理
}

ているが, 最新のナノテクノロジー技術, バイオテクノロ ジー技術に関わる研究に大きくシフトしてきているのが特 徵である.

<教官>

E. Bryan Coughlin

Todd Emrick

Richard J. Farris

Samuel P. Gido

David A. Hoagland

Shaw Ling Hsu

Frank E. Karasz

Alan J. Lesser

\section{<研究内容 $>$}

Synthetic polymer chemistry

Organic aspects of polymer materials chemistry and nanotechnology

Engineering mechanics and thermodynamics

Morphological/structural characterization, Block copolymers , Biopolymers

Polymers in solution and gels, Water-soluble polymers

Surface physics, Spectroscopy of polymers, Phase separation phenomena

Physical chemistry, Electrooptical properties

Deformation \& fracture mechan-

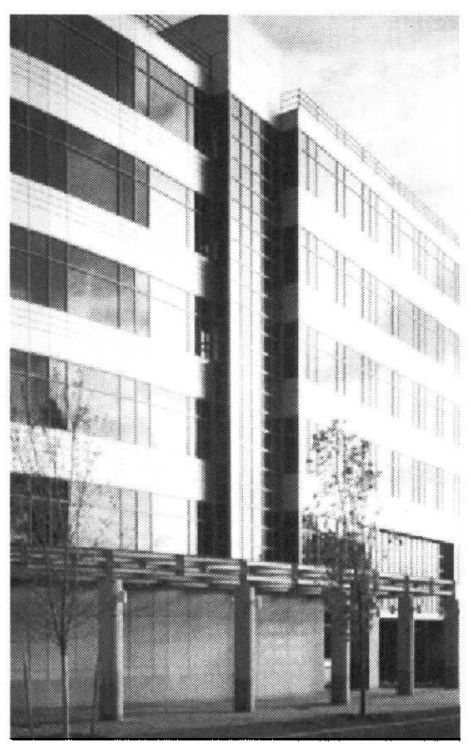

図 2 Silvio 0 Conte National Center For Polymer Research 
ics, Fatigue, Composites, Lifetime estimates Electrolyte surfactant complexes, Polymer blends

Thomas J. McCarthy Organic polymer chemistry, Interface science

Murugappan Muthukumar Theoretical polymer physics

Jacques Penelle

Synthetic chemistry. New methods for the synthesis of advanced polymers

Thomas P. Russell

Polymer physics, Surfaces and interfaces. Functional nanostructures

Maria Santore

Colloidal + Interfacial phenomina, Biomimetic systems

Helmut H. Strey

Biophysics, Biophysical chemistry, X-ray scattering

Gregory N. Tew

Alfred J. Crosby
William J. MacKnight Microphase separated polymers,

- Hierarchical Polymer Materials

\section{2. 新しい高分子成形加工技術への挑戦}

高分子物性 (分子量, ブロック長, 表面/界面エネルギー), 温度，圧力，電場等を高度に制御する成形加工技術により， ナノスケールからミクロンスケールに至るまでの広範囲に 構造制御された高分子材料，バイオテクノロジー材料の研 究が行われている.

1）高分子物性制御による成形加工技術

ブロック共重合体フィルムの厚み, 表面/界面エネルギー を制御することにより，10ナノメートルオーダーのシリ ンダードメインが垂直かつ高密度に配列した材料を形成さ せることが可能となる.このドメインの選択的除去プロセ スにより，10ナノメートルオーダーの高密度かつ均一孔 を有するテンプレートに加工する技術が研究されている

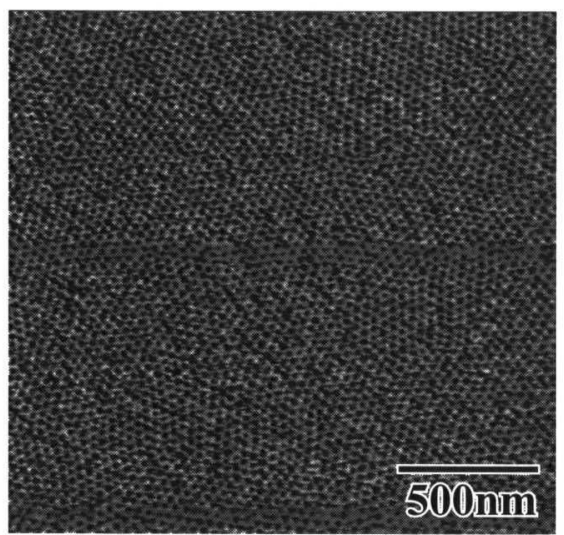

図 3 ナノテンプレート

Silvio O Conte National Center for Polymer Research は，The National Science Foundationにより設立された 材料研究に関するセンター [The Materials Research Science and Engineering Center (MRSEC)] としての機能 も有する. MRSECは，3つの学際的研究グループ，2つ のシードプログラムからなり，他大学，企業との共同研究 の推進を行っている。また，米国内 27 大学とネットワー クを結び，研究を進める上で多くの工夫がなされている. さらに, 高校生, 高校教師, 学部生, 卒業生などへの研究 体験システムを提供しており，教育機関としての役割も 高い.

2 ) Center for UMass/Industry Research on Polymers (CUMIRP)

Center for UMass/Industry Research on Polymers (CUMIRP) は, 1980 年に産学間の研究を担う目的で設立 され，每年春秋 2 回の定期ミーティングを開催している. 現在, 40 以上の企業からの共同研究が行われており，主な 研究は下記の 7 つがある.

- Fire-Safe Polymer \& Polymer Composites

- Green Chemistry, Physics and Engineering of Polymers

- Polyolefin Design

- Mechanics of Polymer, Structure, Properties \& Performance

- Nanoscopic Structures

- Polymers in Bio Arena

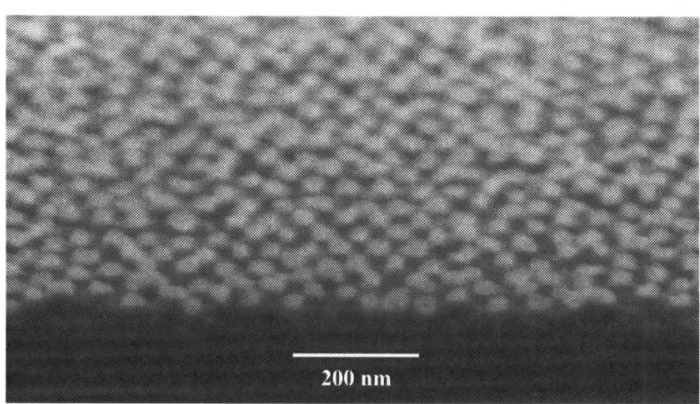

図 4 ナノパターン化無機材料

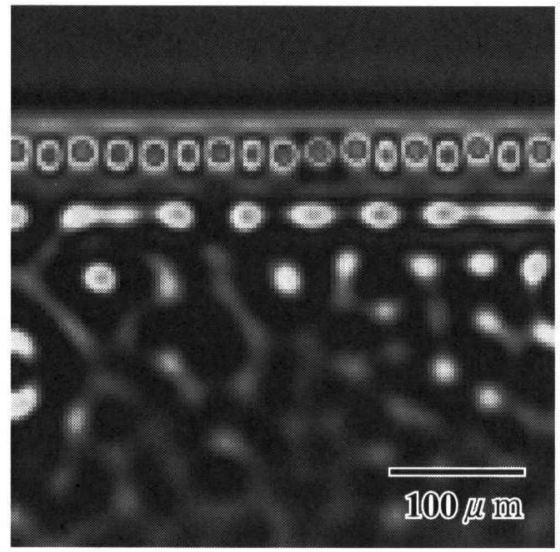

図 5 電界によるマイクロパターン 
(図 3).さらにこのテンプレートをもとに気相反応による 無機材料のナノパターン形成（図 4), 電気めっき法によ るナノワイヤーの成形加工技術も報告されている.

バイオテクノロジーへの応用として, ウイルス合体ペプ チドの挙動を模倣するため，水中に分散したブロック共重 合体のカプセルに界面活性剤を添加することにより，カプ セルの機械特性の制御 (柔軟化) プロセスが研究されている。

2 ）電場を利用した成形加工技術

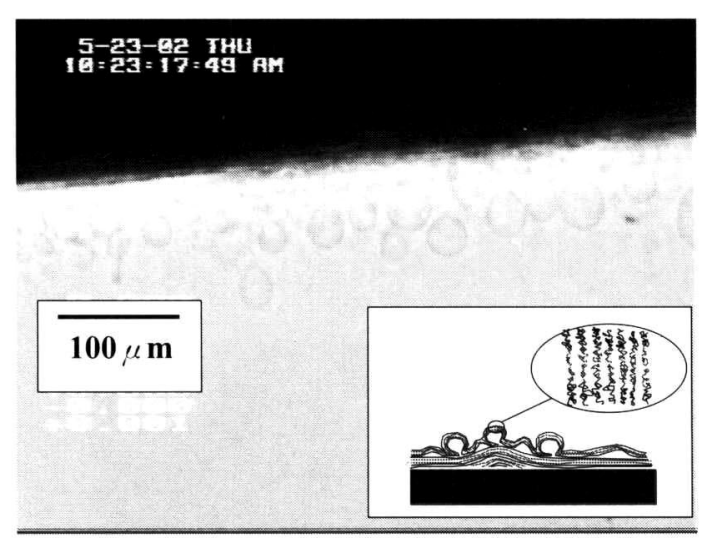

図 6 ラメラ状カプセル

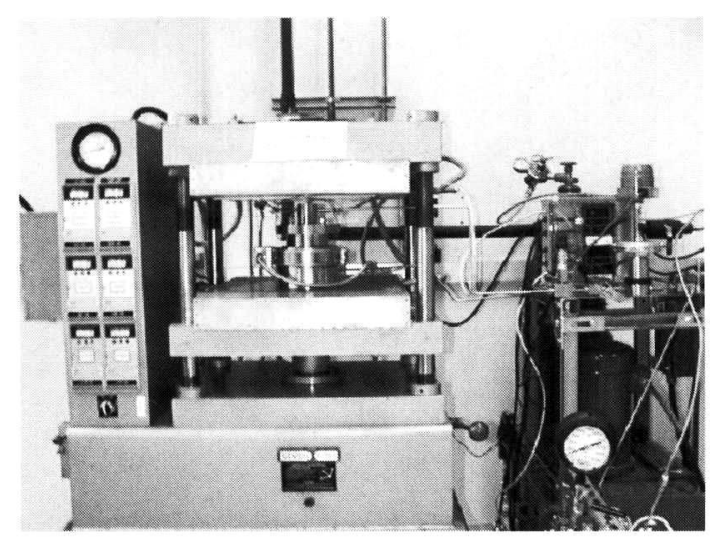

図 7 超臨界ガス成形加工装置

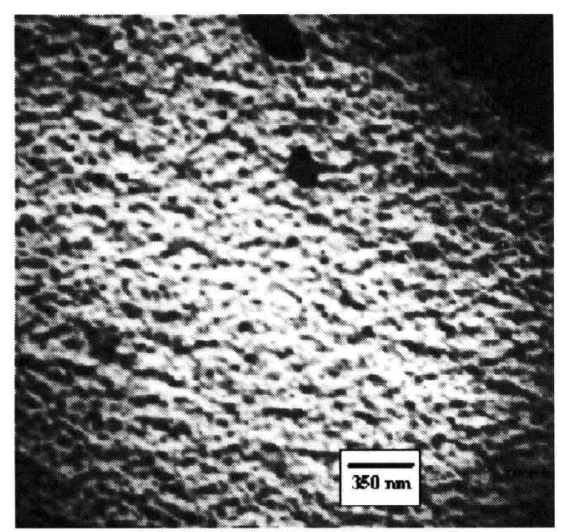

図 8 超臨界ガスによるナノ微細構造形成
高分子薄膜に電場を付与し，電気水力学的不安定状態を 利用して，ナノからミクロンオーダーのパターン化構造を 制御する技術研究が進められている（図 5).

また，ブロック共重合体に電場を付与することによ り，10ナノメートルオーダーのシリンダードメインが電 場方向に沿って配向化する研究結果も得られている.

バイオテクノロジーへの応用として，ブロック共重合体 溶液界面に電界を付与することによるラメラ状カプセルの 形成技術が研究されている（図 6).

3 ）超臨界ガスによる成形加工技術

超臨界二酸化炭素による新しい高分子成形加工プロセス の研究が行われている(図 7)．超臨界ガスによるラミネー トフィルムの接着強度の向上, 超臨界ガスによる瀻維強化 複合材料の機械特性向上等が報告されている．後者の機械 特性向上メカニズムは, 補強綫維表面上に形成された微細 ナノ構造と考えられる（図 8)。

\section{3.おわりに}

Silvio O Conte National Center for Polymer Research は, Polymer Science \& Engineering Department,the Materials Research Science and Engineering Center (MRSEC), Center for UMass/Industry Research on Polymers (CUMIRP) という3つの顔をもつ全米屈指の高分子 に関する研究施設である。そこで研究される内容は多岐に わたり，最新のナノテクノロジー，バイオテクノロジーの 研究動向を常に取り入れながら，基碟研究と応用研究を非 常にバランスよく進めているのが特徴である．また大学間, 学内の研究ネットワーク, 産学の共同研究の取り組みにつ いても優れた組織となっている.

最後に，本稿を作成するにあたりご協力を賜りましたマ サチューセッツ大学アマースト校の Polymer Science \& Engineering Department $の$ Thomas J. McCarthy 教授, Alan J. Lesser 教授, Maria Santore 教授, the Materials Research Science and Engineering Center(MRSEC)の Thomas P. Russell 教授, Center for UMass/Industry Research on Polymers (CUMIRP) $の$ James D. Capistran ディレクターに謝意を表します。

くマサチューセッッ大学アマースト校 Silvio O Conte National Center for Polymer Research $の$ 所在地 $>$

Professor Thomas J. McCarthy, Polymer Science \& Engineering

Silvio O Conte National Center for Polymer Research. University of Massachusetts, Amherst, MA 01002 U.S.A

Tel : + 1-413-577-1512, Fax : + 1-413-577-1510

Home page:http://www.pse.umass.edu (http://www. polymer.org)

E-mail : Masahiro@mail.pse.umass.edu (U.S.A) 